\title{
Characteristic Drying Curve of Oil Palm Fibers
}

\author{
Ifa Puspasari $^{1 *}$, Meor Zainal Meor Talib ${ }^{2}$, Wan Ramli Wan Daud ${ }^{2}$, Siti Masrinda Tasirin ${ }^{2}$ \\ ${ }^{\#}$ Fuel Cell Institute, Universiti Kebangsaan Malaysia, 43600 UKM Bangi, Selangor, Malaysia \\ E-mail: ifa.puspasari@ukm.edu.my
}

*Second Institution, Address, City, ZIP Code, Country 2Department of Chemical and Process Engineering, Universiti Kebangsaan Malaysia, 43600 UKM Bangi, Selangor, Malaysia

\begin{abstract}
The drying of crushed oil palm fronds was studied in a fluidized bed dryer assisted with mechanical agitation at different inlet air temperature, superficial air velocity, bed loading and agitation speed. The drying kinetics of the fibers under various drying conditions could be described by a single characteristic drying curve. A combined exponential and power law model is proposed to represent the characteristic drying curve which described both the increasing rate and the falling rate periods. The proposed model is also tested for drying kinetics of oil palm empty fruit bunch from previous researcher. It was found that the characteristic curve for both oil palm fronds and empty fruit bunch fibers has similar shape and that the proposed model is acceptable for describing the complete drying characteristics of the fibers.
\end{abstract}

Keywords—Characteristic drying curve; Constant rate; Drying kinetics; Falling rate; Fiber; Superheated steam

\section{INTRODUCTION}

Oil palm (Elaeis guineensis) is one of the most important agricultural crops in Malaysia. The oil palm plantation in the country is the highest among other crops, which covers about 4.3 million hectares or $13 \%$ of the total land area in year 2007 and 4.48 million hectares in year 2008 (Department of Statistics Malaysia, 2010). Besides the economic products of vegetable oil, the oil palm tree also generates massive amounts of wastes such as empty fruit bunch, trunk, shell and fronds. Kelly-Yong et al, 2007 reported that each hectare of oil palm plantation produces 10.88 tons of oil palm fronds on the average, which means approximately 46 thousand tons was obtained in the year 2007.

With tremendous amount of oil palm fronds produced by a plantation each year, it has great potential to be utilized as biomass and source of industrial fibers. The fibers can be used as industrial fibers in various products such as fiber boards, mattresses and cushions, thermoplastic fillers, paper and animal feed meal. If wet chopped oil palm frond is exposed to the atmosphere, it degrades easily within a day due to fungal attack and turns brown to black and emit a foul odor. It is therefore essential that the drying of oil palm fronds is done quickly to bring the moisture content to about $10 \%$ wet basis (Supranto et al, 1999; Yun et al, 2013).
Drying of oil palm fibers is difficult to be realized in a fluidized bed dryer due to the elongated shape of the particles and their fibrous nature. These fibers entangled each other and as a result prevented fluidization of the bed. Aeration of the bed in the fluidized bed would form large crack and plug flow as reported by Puspasari et al (2013). They applied mechanical agitation to assist the fluidization of the oil palm fibers.

The concept of characteristic drying curve (CDC) has been successfully applied to describe the drying behavior of many materials ranged from edible to non-edible materials such as bananas (Baini and Langrish, 2007), prickly pear (Lahsasni et al, 2004), sardines (Djendoubi et al, 2009), olive leaves (Nourhene et al, 2008), rosemary leaves (Timoumi and Zagrouba, 2005), sweet pepper (Pal et al, 2008), spirulina (Desmorieux and Decaen, 2005) and nickeliferous laterite ores (Pickels, 2003). The drying characteristic of oil palm fibers from the oil palm empty fruit bunch (EFB) has been studied by Hasibuan and Daud (2007). The drying rate curve for oil palm EFB in a through drying using superheated steam drying progressed with an initial heating period and a falling rate period. No constant rate period was observed. Similar behavior was also observed by Chen and Douglas (1997) for through drying of paper, nevertheless, the constant rate period appeared at low drying intensity. 
This work investigates the characteristics drying curve of oil palm fibers from crushed oil palm fronds. A new model for the complete drying characteristics is proposed and fitted with experimental data. The proposed model is also compared with experimental drying kinetics data for oil palm empty fruit bunch fibers from the work of Hasibuan and Daud (2007) available in the literature.

\section{EQUIPMENT, MATERIALS AND METHODS}

\section{A. Equipment}

Fig. 1 shows the schematic diagram of the experimental apparatus used in this study. Air is supplied by an air blower and passed through an electric heater with temperature control. Air flow rate is measured using a compact hot wire anemometer (Model Testo 425). The air enters the stainless steel plenum chamber and then passes through the distributor plate. The distributor plate is made from stainless steel of 1 $\mathrm{mm}$ thickness with 2-mm holes resulting in 19\% open area. It is covered with a cloth to prevent the particles from falling down into the plenum chamber. The cylindrical column is made of acrylic with a height of $72 \mathrm{~cm}$ and internal diameter of $14.4 \mathrm{~cm}$. At the top of the column, a bag filter is used to separate fines from the discharge gas.

Mechanical agitation is generated by an electric motor (70 watts) with a rotating speed varying from 100 to $2000 \mathrm{rpm}$. The agitator consists of four impellers mounted on a $1 \mathrm{~cm}$ diameter stainless steel shaft. The type of impeller used is pitched blade turbine having an angle of $30^{\circ}$ with horizontal. The total blade length is $12 \mathrm{~cm}$ and it is $0.15 \mathrm{~cm}$ thick. The detail of the agitator is shown in Fig. 2.

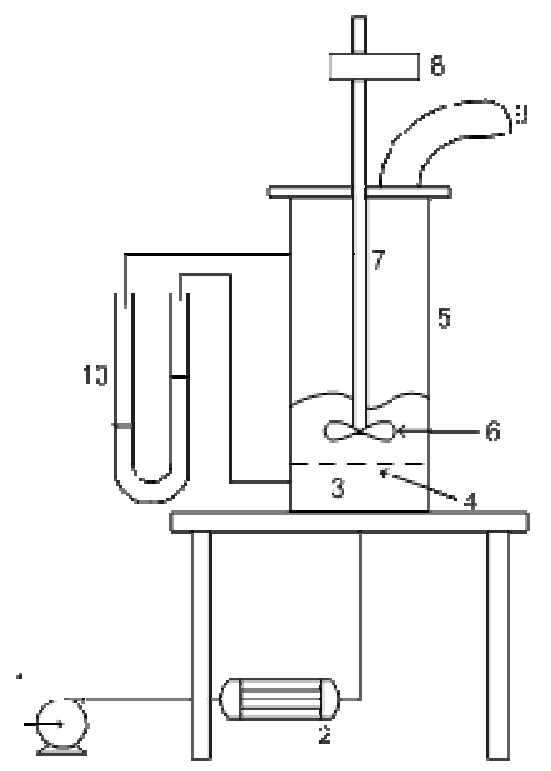

Fig. 1. Schematic diagram of agitated bed dryer: 1. Air blower, 2. Heater, 3. Plenum chamber, 4. Distributor plate, 5. Column, 6. Impeller, 7. Shaft, 8. Agitator motor, 9. Bag filter, 10. Water manometer

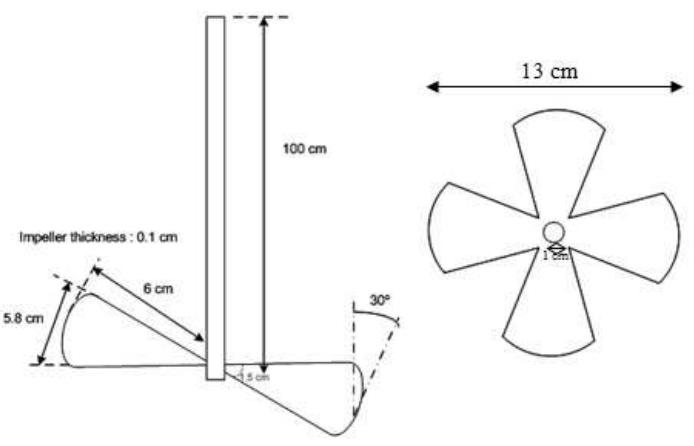

Fig. 2 Shape and size of agitator

\section{B. Materials}

Wet oil palm fronds used in this study were obtained from Bangi, Selangor, Malaysia. After removing the leaves, the oil palm fronds was then cut into small pieces $(40 \mathrm{~mm})$ and ran through a mechanical crusher (Cheso Cresher Model LCT $10 \mathrm{HP}$ ). Fig. 3 shows photograph of the crushed oil palm fronds.

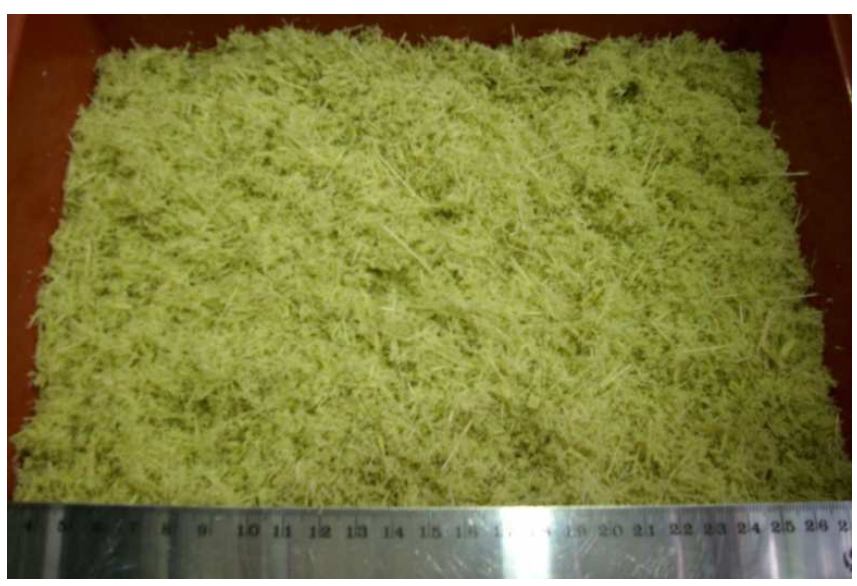

Fig. 3 Photograph of crushed oil palm fronds

\section{Experimental Method}

In this work, the Design of Experiments of Taguchi method was used which allows the effects of various parameters to be simultaneously determined effectively and efficiently. By using Taguchi method, the number of experiments is less compared to the Full Factorial method of design of experiments. A total of 9 experiments were carried out according to the L-9 array of Taguchi method. It consists of four factors and three levels for each factor as shown in Table 1. For each experiment, the wet crushed oil palm fronds were charged into the top of the column and the drying experiment was started at predetermined inlet air temperature, inlet air velocity, bed loading and agitation speed. The data on the moisture content of the particles were collected by taking a sample of approximately $1 \mathrm{~g}$ from the bed every two minutes. The sample was weighed and placed in an oven set at $105^{\circ} \mathrm{C}$ for moisture content determination. 
TABLE I

EXPERIMENTAL DESIGN

\begin{tabular}{cccccc}
\hline $\begin{array}{c}\text { Experiment } \\
\#\end{array}$ & $\begin{array}{c}\text { Designati } \\
\text { on }\end{array}$ & $\begin{array}{c}T \\
\left({ }^{\circ} \mathrm{C}\right)\end{array}$ & $\begin{array}{c}u \\
(\mathrm{~m} / \mathrm{s})\end{array}$ & $\begin{array}{c}B \\
(\mathrm{~g})\end{array}$ & $\begin{array}{c}N \\
(\mathrm{rpm})\end{array}$ \\
\hline 1 & 1111 & 50 & 0.6 & 200 & 300 \\
2 & 1222 & 50 & 0.8 & 250 & 400 \\
3 & 1333 & 50 & 1.0 & 300 & 500 \\
4 & 2123 & 60 & 0.6 & 250 & 500 \\
5 & 2231 & 60 & 0.8 & 300 & 300 \\
6 & 2312 & 60 & 1.0 & 200 & 400 \\
7 & 3132 & 80 & 0.6 & 300 & 400 \\
8 & 3213 & 80 & 0.8 & 200 & 500 \\
9 & 3321 & 80 & 1.0 & 250 & 300 \\
\hline
\end{tabular}

\section{Characteristic Drying Curve}

The concept of characteristic drying curve (CDC) first proposed by van Meel (1958) and cited in Keey (1978) consists of normalizing the moisture content and the drying rate. The curve is obtained by plotting $f$ against $\Phi$ where $f$ is the normalized drying rate and $\Phi$ is the normalized moisture content defined as

$$
\begin{gathered}
f=\frac{\left(\frac{d X}{d t}\right)}{\left(\frac{d X}{d t}\right)_{\mathrm{er}}} \\
\phi=\frac{X-X_{\mathrm{eq}}}{X_{\mathrm{er}}-X_{\mathrm{eq}}}
\end{gathered}
$$

The initial drying period is usually short and neglected in the drying model. However, in this work, since the initial period took almost one-third of the total drying process, it should be incorporated in the drying model to well describe the complete drying characteristics. Therefore, the moisture content is then normalized to the initial moisture content as suggested by Daud et al. (2000) in Eqn. (3) to describe the whole drying process.

$$
\mu=\frac{X-X_{\mathrm{eq}}}{X_{o}-X_{\mathrm{eq}}}
$$

A combined exponential and power law function is proposed as shown in Eqn. (4) to represent the relationship between drying rate and moisture content. Similar concept was formerly proposed by Puspasari et al (2012) when developing the composite drying model.

$$
f=a \mu^{n} \exp \left(-k \mu^{m}\right.
$$

where the values of $\mathrm{n}$ and $\mathrm{m}$ are given by

$n<1$ $m>1$

Taking logs on both sides:

$$
\ln f=\ln \alpha+n \ln \mu-k \mu^{2}
$$

Hence there are two drying regimes: the increasing drying rate with decreasing moisture content, known as the increasing rate period, and the decreasing drying rate with decreasing moisture content, known as the falling rate period. If the dimensionless moisture content, $\mu$ approaches zero, $n$ is more dominant. In other words at dryer conditions, hindered internal diffusion is dominant. Conversely, if the dimensionless moisture content, $\mu$ approaches $1, \mathrm{~m}$ is more dominant. In other words at wetter conditions, variation of diffusion with position is dominant (Puspasari et al, 2012).

\section{RESULTS AND DISCUSSION}

All paragraphs must be indented. All paragraphs must be justified, i.e. both left-justified and right-justified.

The drying rates of crushed oil palm fronds at various drying conditions are shown in Fig. 4. The drying rates were then normalized and presented in Fig. 5. As shown in Fig. 5, the curves are close together indicating that the effect of different drying conditions is small over the range tested in this work. By fitting Eqn. (4) with the experimental drying rate data for oil palm frond fibers, the following characteristic equation was obtained:

$$
f=1.99 \mu^{0.79} \exp \left(-1.13 \mu^{1.96}\right.
$$

with correlation coefficient $\mathrm{r}=0.9681$ and standard error $\mathrm{Sr}$ $=0.0865$ which shows a good fit to the experimental data.

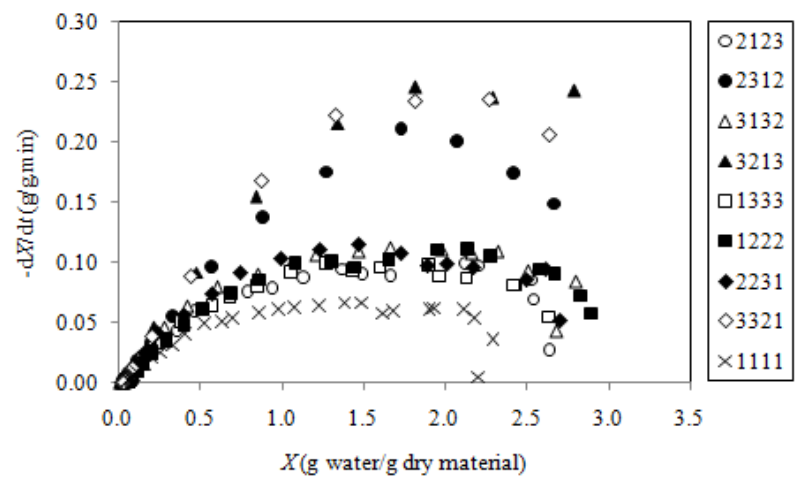

Fig. 4. Drying rate curve of crushed oil palm fronds

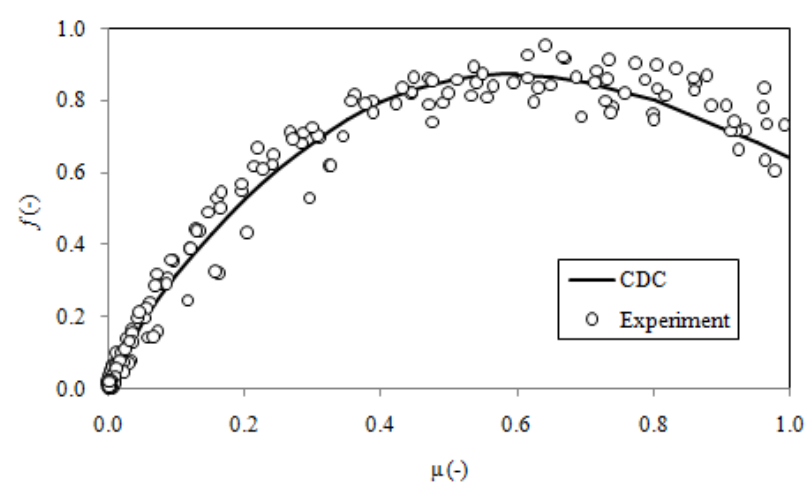


Fig. 5. Characteristic drying curve of crushed oil palm fronds

The CDC method also could be applied to describe the drying kinetics of oil palm empty fruit bunch. It was observed that the shapes of the drying curves for oil palm empty fruit bunch in superheated steam do not significantly differ with temperature over the range studied (steam temperatures of between $115-170{ }^{\circ} \mathrm{C}$ and steam velocities from $0.35-0.49 \mathrm{~m} / \mathrm{s}$ ). A characteristic curve seems to appear for the oil palm empty fruit bunch fibers. On the contrary, Langrish (2008) found that for the drying of sugar beet fibers from the work of Pronyk et al. (2004), the characteristic drying curve was only observed in hot air and not in superheated steam. Since the shape of the drying rate curve for oil palm empty fruit bunch is similar with that of oil palm fronds, the drying data from Hasibuan and Daud (2007) for through drying of oil palm empty fruit bunch fibers could be fitted to Eqn. (4). The characteristic drying curve is shown in Fig. 6 with the following equation:

$$
f=1.25 \mu^{0.90} \exp \left(-2.39 \mu^{16.18}\right.
$$

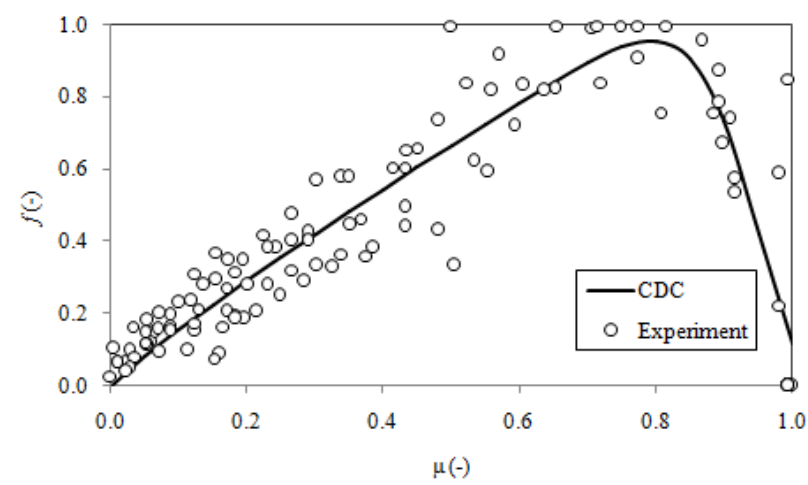

Fig. 6. Characteristic drying curve of empty fruit bunch

This composite drying model can only be applied when the drying curve exhibits no constant rate period. If the drying progresses with the existence of constant rate period as in the drying of orange peel (Tasirin et al, 2013; Tasirin et al, 2014), the composite drying model can be applied by normalizing the moisture content and the drying rate with the respect to the critical moisture.

\section{CONCLUSIONS}

The fluidized bed drying of crushed oil palm fronds has been investigated. The drying rate curve exhibits an increasing rate period followed with a falling rate period. It was found that a single characteristic drying curve exists for the drying of oil palm fronds under various drying conditions. Similar characteristic was also found for the drying of oil palm empty fruit bunch. A model which is combination of exponential and power law function was proposed to represent the complete drying characteristics of the fibers. The values of the parameters for oil palm fronds are $\mathrm{a}=1.99, \mathrm{n}=0.79, \mathrm{k}=1.13, \mathrm{~m}=1.96$, whereas for oil palm empty fruit bunch are $\mathrm{a}=1.25, \mathrm{n}=0.90, \mathrm{k}=2.39$, and $\mathrm{m}=16.18$.

\section{NOMENCLATURE}

$\begin{array}{ll}\mathrm{a}, \mathrm{n}, \mathrm{k}, \mathrm{m} & \text { Equation parameters } \\ \mathrm{B} & \text { Bed loading, } \mathrm{g} \\ \mathrm{f} & \text { Normalized drying rate, }- \\ \mathrm{N} & \text { Agitation speed, rpm } \\ \mathrm{r} & \text { Correlation coefficient } \\ \mathrm{Sr} & \text { Standard error } \\ \mathrm{t} & \text { Drying time, } \mathrm{min} \\ \mathrm{T} & \text { Temperature, }{ }^{\circ} \mathrm{C} \\ \mathrm{u} & \text { Velocity, } \mathrm{m} / \mathrm{s} \\ \mathrm{X} & \text { Moisture content (dry basis), g water/g dry material }\end{array}$

Symbol:

$\Phi, \mu \quad$ Normalized moisture content, -

Subscripts:

$\begin{array}{ll}\text { eq } & \text { Equilibrium } \\ \mathrm{cr} & \text { Critical } \\ \mathrm{o} & \text { Initial }\end{array}$

\section{REFERENCES}

[1] Baini, R. and Langrish, T.A.G. Choosing an appropriate drying model for intermittent and continuous drying of bananas. Journal of Food Engineering, 2007, 79, 330-343.

[2] Chen, G. and Douglas, W.J.M. Through drying of paper. Drying Technology, 1997, 15(2), 295-314.

[3] Daud, W.R.W., Sarker, M.N.H. and Talib, M.Z.M. Drying characteristics of Malaysian Padi. Pertanika Journal of Science and Technology, 2000, 8(1), 105-115.

[4] Department of Statistics Malaysia. Report on the census of agricultural establishments 2009. <http://www.statistics.gov.my/portal/images/stories/files/LatestRelea se/agricultural/Ringkasan_Penemuan_2009_TANAMAN>

[5] Desmorieux, H. and Decaen, N. Convective drying of spirulina in thin layer. Journal of Food Engineering, 2005, 66, 497-503.

[6] Djendoubi, N., Boudhrioua, N., Bonazzi, C. and Kechaou, N. Drying of sardine muscles: Experimental and mathematical investigations. Food and Bioproducts Processing, 2009, 87, 115-123.

[7] Hasibuan, R. and Daud, W.R.W. Through drying characteristic of oil palm empty fruit bunch (EFB) fibers using superheated steam. AsiaPacific Journal of Chemical Engineering, 2007, 2(1), 35-40.

[8] Keey, R.B. Introduction to Industrial Drying Operations. Pergamon Press; Oxford, 1978, 164-165.

[9] Kelly-Yong, T. L., Lee, K. T., Mohamed, A. R., \& Bhatia, S. Potential of hydrogen from oil palm biomass as a source of renewable energy worldwide. Energy Policy, 2007, 35, 5692-5701.

[10] Lahsasni, S., Kouhila, M., Mahrouz, M. and Jaouhari, J.T. Drying kinetics of prickly pear fruit (Opuntia ficus indica). Journal of Food Engineering, 2004, 61, 173-179.

[11] Langrish, T.A.G. Characteristic drying curves for cellulosic fibres. Chemical Engineering Journal, 2008, 137, 677-680.

[12] Nourhene, B., Mohammed, K. and Nabil, K. Experimental and mathematical investigations of convective solar drying of four varieties of olive leaves. Food and Bioproducts Processing, 2008, 86, 176-184.

[13] Pal, U.S., Khan, M.K. and Mohanty, S.N. Heat pump drying of green sweet pepper. Drying Technology, 2008, 26, 1584-1590.

[14] Pickles, C.A. Drying kinetics of nickeliferous limonitic laterite ores Minerals Engineering, 2003, 16, 1327-1338.

[15] Pronyk, C., Cenkowski, S., and Muir, W.E. Drying foodstuffs with superheated steam. Drying Technology, 2004, 22(5), 899-916.

[16] Puspasari, I., Talib, M.Z.M., Daud, W.R.W., Tasirin, S.M. Drying kinetics of oil palm frond particles in an agitated fluidized bed dryer. Drying Technology, 2012, 30(6), 619-630

[17] Puspasari, I., Talib, M.Z.M., Daud, W.R.W., Tasirin, S.M. Fluidization characteristics of oil palm frond particles in agitated bed. Chemical Engineering Research and Design, 2013, 91, 497-507.

[18] Supranto; Daud, W.R.W.; Sopian, K.; Othman, M.Y.; Yatim, B. Drying curves of oil palm fronds. In Proceedings of First Asian- 
Australian Drying Conference (ADC'99), Bali, Indonesia, 1999; 281289.

[19] Tasirin, S.M., Puspasari, I., Sahalan, A.Z., Mokhtar, M., Ghani, M.K.A., Yaakob, Z. Drying of Citrus sinensis peels in an inert fluidized bed: Kinetics, microbiological activity, vitamin C, and limonene determination. Drying Technology, 2014, 32(5), 497-508.

[20] Tasirin, S.M., Puspasari, I., Xing, L.J., Yaakob, Z., Ghani, J.A. Energy optimization of fluidized bed drying of orange peel using Taguchi method. World Applied Sciences Journal, 2013, 26(12), 1602-1609.
[21] Timoumi, S. and Zagrouba, F. Water sorption and dehydration kinetics of Tunisian rosemary leaves. Desalination, 2005, 185, 517521.

[22] Van Meel, D.A. Adiabatic convection batch drying with recirculation of air. Chemical Engineering Science 1958, 9(1), 36-44.

[23] Yun, T.M., Puspasari, I., Tasirin, S.M., Talib, M.Z.M., Daud, W.R.W., Yaakob, Z. Drying of oil palm frond particles in a fluidized bed dryer with inert medium. Chemical Industry \& Chemical Engineering Quarterly, 2013, 19(4), 593-603. 